\title{
28. A LAMINA-SCALE, SEM-BASED STUDY OF A LATE QUATERNARY DIATOM-OOZE SAPROPEL FROM THE MEDITERRANEAN RIDGE, SITE 971 ${ }^{1}$
}

\author{
Richard B. Pearce, ${ }^{2}$ Alan E.S. Kemp, ${ }^{2}$ Itaru Koizumi, ${ }^{3}$ Jennifer Pike, ${ }^{2}$ Adrian Cramp,${ }^{4}$ and Stephen J. Rowland ${ }^{5}$
}

\begin{abstract}
A scanning electron microscope-based study of a laminated, late Quaternary sapropel from the moat of the Napoli mud volcano provides a new insight into the seasonal-scale sequence of fluxes involved in sapropel deposition. The sapropel is essentially an organic-rich diatom ooze in which the opal has been preserved in a topographic depression whose bottom waters were, at least intermittently, cut off from the silica-undersaturated waters characteristic of the Mediterranean. Back-scattered electron imagery of polished, resin-impregnated thin sections of this bed demonstrate an alternation of laminae containing diatoms from the family Rhizosoleniaceae, hereafter referred to as rhizosolenid diatoms, with laminae containing mixed assemblages including typical diatom bloom species. The occurrence of the rhizosolenid laminae are evidence for seasonal-scale mass sedimentation of diatoms in the form of diatom mats. These diatom mats may represent the deep chlorophyll maximum inferred to have existed during periods of sapropel formation documented by foraminifer and nannofossil studies. The mat-sedimentation model for the deposition of sapropels is consistent with both (1) the presence of stratified conditions in which nutrients trapped at depth could be exploited only by the vertically migrating mats; and (2) the evidence for high export production that occurred by massive sedimentation of mats following the intermittent breakdown of stratification.
\end{abstract}

\section{INTRODUCTION}

The extensive multidisciplinary studies that have been undertaken in the quest to understand the origins of the Mediterranean sapropels have included detailed micropaleontological and isotopic investigations to deduce phytoplankton and zooplankton paleohabitats. Yet none (with the sole exception of Schrader and Matherne, 1981) have attempted to use evidence from the remains of the world's most important primary producers - the diatoms. This scarcity is, however, entirely understandable since diatom frustules are rarely preserved in post-Messinian Mediterranean sediments. The purpose of this paper is to report the preliminary results of a study of an exceptionally wellpreserved, late Quaternary diatomaceous sequence from the Eastern Mediterranean that brings important new evidence to bear on models of sapropel genesis.

The analysis of Schrader and Matherne (1981), in common with most previous micropaleontological studies, was based on the use of homogenized sediment samples, yet recent observations of diatom blooms and their sedimentation have demonstrated that often monospecific pulses that closely reflect changes in ecological conditions are generated (see summary in Sancetta, 1996). To exploit the resolution available in laminated sediments that record successive flux events, electron microscope techniques have been successfully employed in a number of settings (e.g., Pike and Kemp, 1996b; Kemp and Baldauf, 1993; Kemp, 1996, and references therein). These studies have resolved the deposits of individual diatom blooms, and "nonbloom" diatom flux events that have recorded intra-annual succession in species. The objective of this study is to bring the proven scanning

${ }^{1}$ Robertson, A.H.F., Emeis, K.-C., Richter, C., and Camerlenghi, A. (Eds.), 1998. Proc. ODP, Sci. Results, 160: College Station, TX (Ocean Drilling Program).

${ }^{2}$ Department of Oceanography, University of Southampton, Southampton Oceanography Centre, European Way, Southampton, SO14 3ZH, United Kingdom

Richard.B.Pearce@soc.soton.ac.uk

${ }^{3}$ Division of Earth and Planetary Sciences, Graduate School of Science, Hokkaido University, Sapporo, 060, Japan.

${ }^{4}$ Department of Earth Sciences, University of Wales Cardiff, P.O. Box 914, CF1 3YE, United Kingdom.

${ }_{5}^{5}$ Department of Environmental Sciences, University of Plymouth, Plymouth, PL4 8AA, United Kingdom. electron microscope (SEM)-based approach to bear on the laminated diatomaceous sapropels encountered at the Napoli dome.

As silica dissolution may completely destroy diatoms (and has clearly done so throughout much of the Mediterranean), other means were employed to determine the possible original presence of diatoms. To add to the scope of the present study, biomarker methods were employed to establish if the diatoms in the sapropel could be characterized in sapropels where silica dissolution had removed biogenic opal. One of the most stimulating and intriguing aspects of scientific drilling is its propensity for producing the unexpected. This serendipity factor is, if anything, enhanced on multi-objective legs during which scientists from different disciplines cast their eyes on new and unfamiliar sediments. Unsurprisingly, perhaps, such was the case on Ocean Drilling Program (ODP) Leg 160, where many of the tectonic sites produced new and important paleoceanographic perspectives, not least at Site 971 on the Mediterranean Ridge.

\section{Bathymetric and Geo-Tectonic Setting}

Coring at ODP Site 971 (Fig. 1) targeted the Napoli mud volcano, one of a series of submarine edifices on the Mediterranean Ridge, which is an extensive area of mud volcanism/diapirism related to upward escape of overpressured material (Robertson et al., 1996). A multihole transect was designed to determine the nature and history of activity of the mud volcano. The initial hole (Hole 971A) was taken at a water depth of $2037.5 \mathrm{~m}$ on the outer flank of the Napoli dome, outboard of the moat. The next hole of the transect (Hole 971B) was located at a water depth of $2152 \mathrm{~m}$ within the moat (Fig. 2). As abundant diatoms were found in the core catcher of the second core of Hole 971B (Core 160-971B-2H), an additional hole (Hole 971C) was cored to recover the full interval of diatom-bearing sediments in the coring gap between Cores 160-971B-2H and 3H (Fig. 3).

\section{Sedimentology of Late Quaternary Sequence at Site 971}

The upper part of the sedimentary sequence in Holes 971A, 971B and 971C is shown in Figure 3. The sediments comprised a normal sequence of pale gray nannofossil clays with interbedded dark sapropels resting on mud-volcano deposits. The naming of sapropels (S1-S5) was undertaken with reference to other Leg 160 Sites and to 


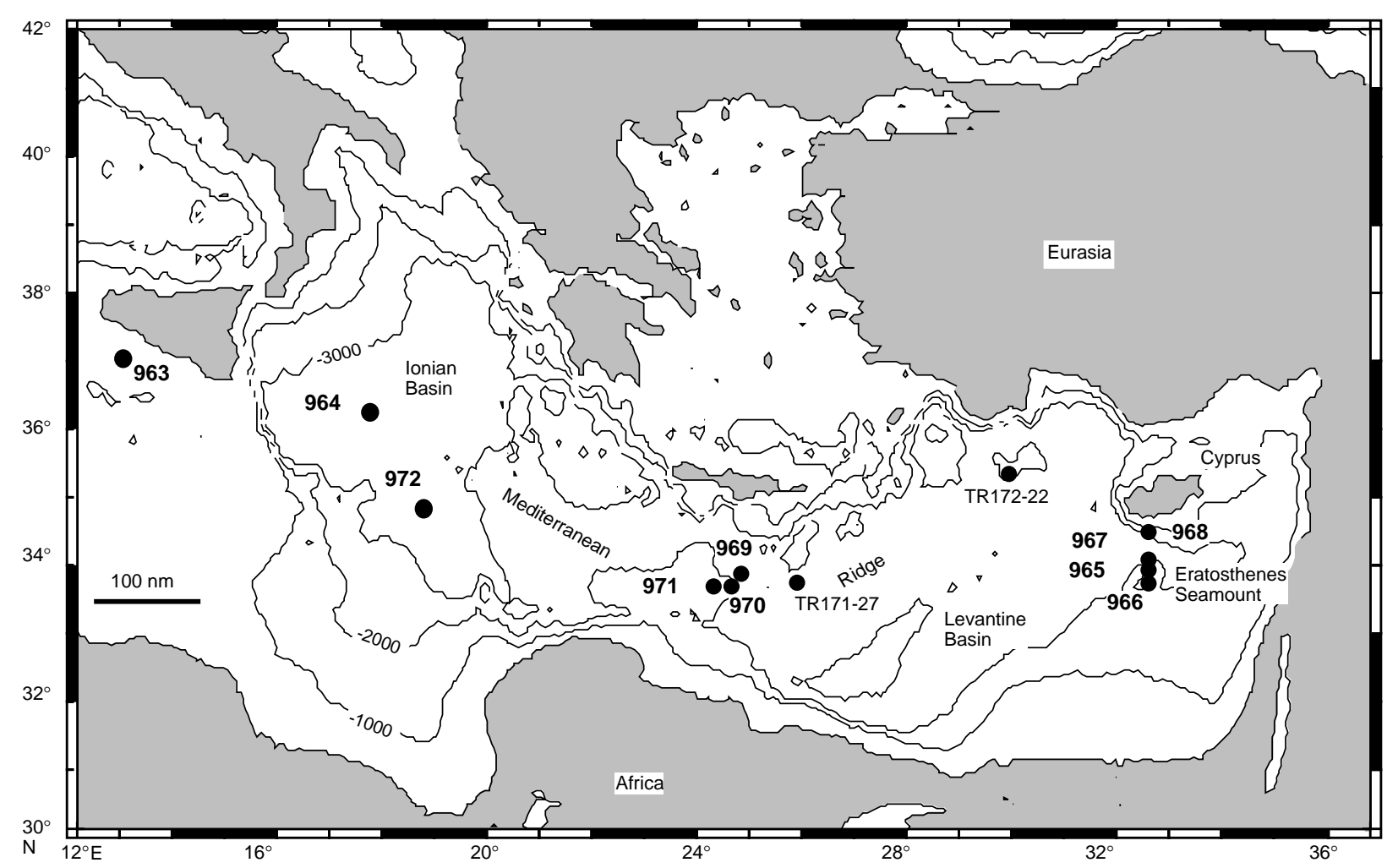

Figure 1. Map of the Mediterranean showing the locations of ODP Leg 160 coring sites and piston core sites TR171-27 and TR172-22, which contain S5 diatoms from Schrader and Matherne (1981). Piston cores TR171-27 and TR172-22 were collected during R/V Trident cruises 171 and 172 . Contours are in meters below sea level.

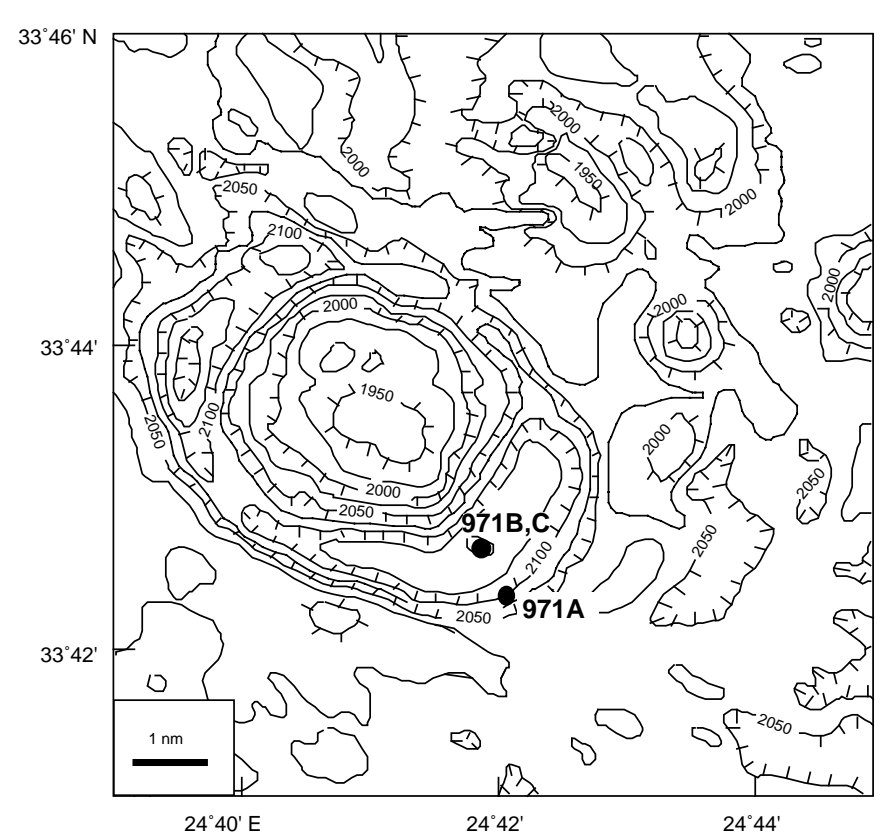

Figure 2. Bathymetric profile of the Napoli mud volcano showing the locations of Holes 971A, 971B, and 971C. existing lithostratigraphic criteria (e.g., Cita et al., 1982). The sequence in Hole 971A is straightforward, containing sapropels that appear normal in thickness and sequence. Comparison and correlation with the composite section formed by Holes 971B and 971C demonstrates the marked difference in thickness of the upper $12 \mathrm{~m}$ of the section. The thickness of sediment between the base of Sapropel S1 and its suprajacent manganese oxide-rich layer is $19 \mathrm{~cm}$ in Hole 971 A and increases to $60 \mathrm{~cm}$ in Holes 971B and 971C (Fig. 3). Similarly, the total thickness of sediment overlying the ash above Sapropel S5 is $2.2 \mathrm{~m}$ in Hole 971A but $5.7 \mathrm{~m}$ in Hole 971C. Sapropel S3 exhibits some internal laminations, suggesting redeposition of material during its sedimentation, and a $\sim 60-\mathrm{cm}$-thick zone of contorted sediment, probably a debris flow, occurs below Sapropel S3 in Hole 971B. Some thin laminae and beds of sapropel-type sediment occur within the nannofossil clay beneath the zone of contorted bedding. The top of the thick diatomaceous sapropel (correlated with S5 in Hole 971 A) occurs at $10.2 \mathrm{mbsf}$ in Hole 971B and $8.6 \mathrm{mbsf}$ in Hole 971C. This bed is described in detail below. Beneath the diatomaceous sapropel in Holes 971B and 971C, two sapropels that closely resemble their probable counterparts in Hole 971A occur. Beneath these beds there is a transition, marked by color-grading to mud volcano deposits (see Robertson and Kopf, Chap. 50, this volume). A bulk sedimentation rate for the sedimentary sequence at Site 971 (assuming S5 has been correctly correlated) would be $\sim 10 \mathrm{~cm} / 1000 \mathrm{yr}$.

After diatoms were discovered in Section 160-971B-2H-6, examination of other sapropel horizons in Hole 971B showed that no other horizons contained preserved opal. Organic carbon analyses (from shipboard analyses) gave values of between $2 \%$ and $7 \%$ for the sapropels in Hole 971A, 3\% for the thick Sapropel S1 in Hole 971B and $4 \%-7 \%$ for the upper part of the diatomaceous sapropel in Hole 971B. 


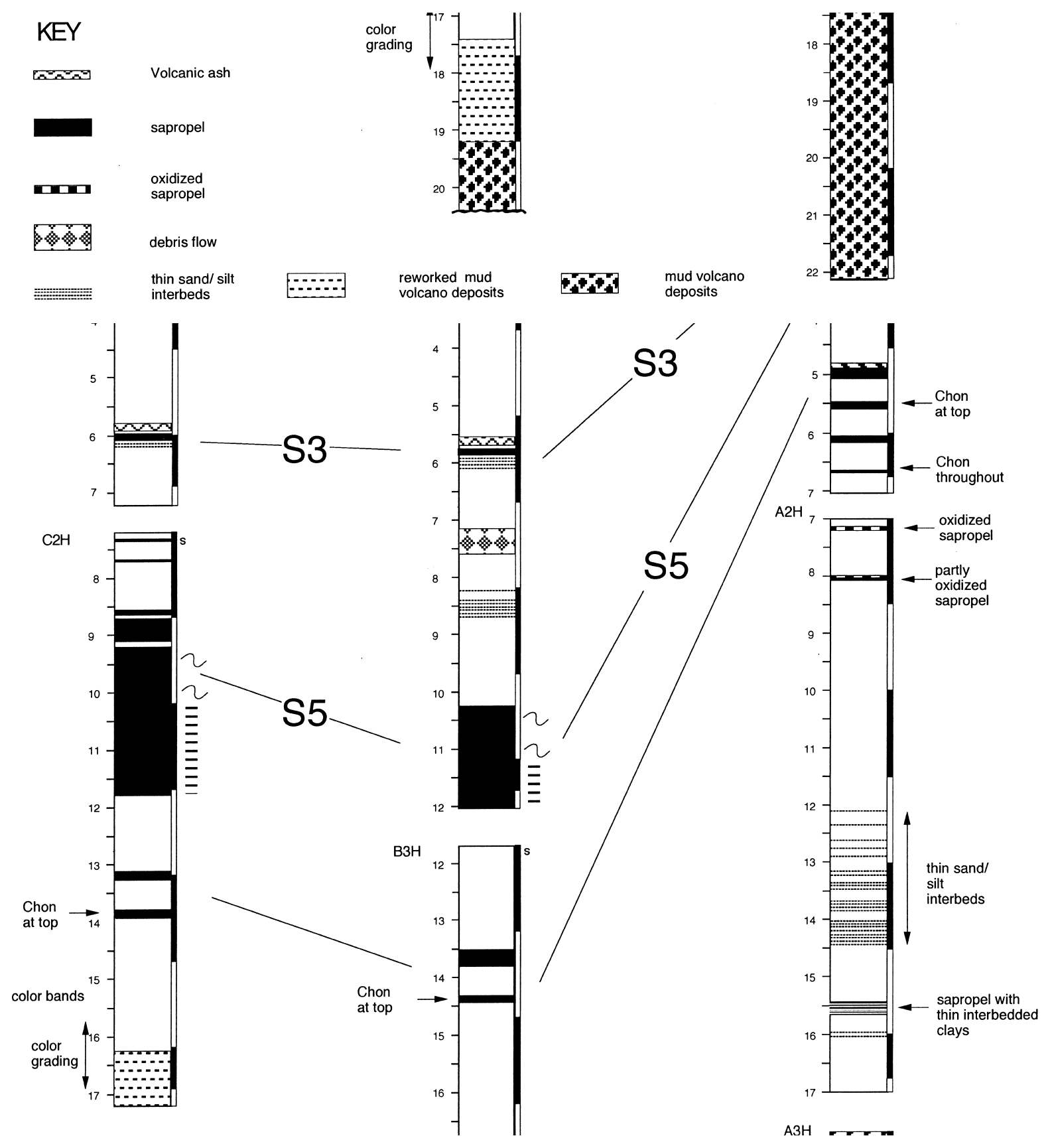

Figure 3. Detailed core summaries showing the lithostratigraphic correlation between Hole 971A, located outboard of the rim of the Napoli moat and Holes 971B, 971C, which were cored in adjacent locations within the Napoli moat (see Fig. 2). The correlation between sapropels within the sites is based on sequence and sedimentological characteristics. Chon $=$ Chondrites. 
The laminated diatomaceous sapropel ( $\mathrm{Pl} .1$ ) was described in detail in Hole 971C, and continuous samples were taken for SEM-based investigations. A sketch of the cored interval containing the sapropel is shown in Figure 4. Although the overall thickness of this horizon is $2.3 \mathrm{~m}$, it is internally composite and locally deformed. There is a small slump fold at the base, which is overlain by $70 \mathrm{~cm}$ of intact, undeformed laminated sediment. This is overlain by $80 \mathrm{~cm}$ of laminated sediment that contains internal contortions and microfaults that disrupt the laminae. Fifteen centimeters of more intact sediment is overlain by an $85 \mathrm{~cm}$ unit containing a recumbent slump-fold and a discontinuity above which a 10-cm-thick horizon of nannofossil clay occurs. A further 55-cm-thick sapropel layer occurs with a thin nannofossil clay near the top, which may duplicate the subjacent bed. Given the presence of slump folds and the possibility of duplication by slumping, the original thickness of the layer may be less than 2.3 $\mathrm{m}$, but must be at least $80 \mathrm{~cm}$ - the thickness of the intact, undeformed part.

\section{METHODS SEM Techniques}

Sediment samples were prepared for SEM study by impregnation using epoxy resin. This was undertaken either by vacuum impregnation in a Logitech vacuum impregnation apparatus or modified from the displacive fluid impregnation method described in Pike and Kemp (1996a; see Kemp et al., Chap. 27, this volume). For the initial lamina-scale studies, priority was given to the intact part of the horizon. The intervals prepared for sectioning are indicated on Figure 4.

Low-resolution, back-scattered electron imagery (BSEI) was used to provide base maps for more detailed imagery of lamina composition. Subsamples of sediment were prepared for topographic secondary electron and BSEI to provide analysis of microfossil components. Identification of changes in diatom species composition from BSEI study across interval $160-971 \mathrm{C}-2 \mathrm{H}-3,126.7-129 \mathrm{~cm}$, were used as a basis for separation of 18 lamina-scale samples for ultra-high resolution biomarker studies and/or micropaleontological analyses. The estimated extent of the diatom and biomarker subsamples are shown on Figure 5. Every attempt was made to sample as near as possible to specific laminae or sublaminae based on the BSEI images; however, the thinness of the laminae militated against this.

\section{Quantitative Diatom Micropaleontological Analysis}

Quantitative diatom slides were prepared. Dried material was weighed and boiled in a $100 \mathrm{~mL}$ beaker with about $10 \mathrm{~mL}$ of hydrogen peroxide solution (15\%) for several seconds, diluted with distilled water, and then left to stand for $24 \mathrm{hr}$. After decanting, the residue was diluted with the proper amount, which was in proportion to $0.025 \mathrm{~g}$ in $25 \mathrm{~mL}$ of distilled water (for example: $57.6 \mathrm{~cm}^{3}$ to 0.0576 $\mathrm{g}$ of Sample $1 / 1-5 ; 27 \mathrm{~cm}^{3}$ to $0.0270 \mathrm{~g}$ of Sample 1/6-8, etc.) and homogenized for $3 \mathrm{~s}$ in an ultrasonic washer. Using a micropipette, 0.25 $\mathrm{mL}$ of this solution was placed on a cover glass $(18 \times 18 \mathrm{~mm}$ in size $)$, dried on a hot plate at $50^{\circ} \mathrm{C}$, and then mounted on a glass slide using Pleurax. All diatoms were identified and counted until the number of individual specimens reached a total of 200, excluding Chaetoceros spp. resting stages.

\section{Biomarker analysis}

The diatom Rhizosolenia setigera is the only known producer of $\mathrm{C}_{30}$, which are known as highly branched isoprenoid hydrocarbons (HBIs; Robson and Rowland, 1988; Volkman et al., 1994). A search for these compounds was, therefore, made in selected sediments in which Rhizosolenia spp. tests were identified as abundant (see below). The method involved solvent extraction, isolation of a hydro- carbon fraction by column chromatography, and analysis of the fractions by gas chromatography-mass spectrometry (GC-MS). The synthetic $\mathrm{C}_{30}$ alkenes (Robson and Rowland, 1988), published retention indices, and mass spectra were used as reference materials.

Seven sediment samples were weighed, freeze-dried, and reweighed (dry weight) before extraction as shown in Table 1. Each sample was then spiked with $0.5 \mu \mathrm{g}$ of internal standard $(2,21$-dimethyldocosane) and solvent extracted with hexane for $24 \mathrm{hr}$. The total hexane extract (THE) was concentrated by rotary evaporation to $\sim 1 \mathrm{~mL}$ and transferred to a clean preweighed vial. The remaining solvent was removed under a gentle stream of nitrogen, and the mass of extract was recorded (Table 1$)$. After derivation with BSTFA $(10 \mu \mathrm{L}$ in sample; $60^{\circ} \mathrm{C}$ for $30 \mathrm{~min}$ ), an aliquot of the THE was examined by GC-MS (Fig. 6).

The remaining THE was further fractionated using a Pasteur pipette packed with $5 \%(\mathrm{w}: \mathrm{w})$ deactivated silica, and then eluting with hexane to obtain a hydrocarbon fraction $\left(\mathrm{F}_{1}\right)$. (A second fraction $\left(\mathrm{F}_{2}\right)$ was also obtained by elution with dichloromethane (DCM), but results are not given here.) Solvent was removed from each fraction under a stream of nitrogen, and the hydrocarbon fractions $\left(\mathrm{F}_{1}\right)$ were analyzed by gas chromatography (GC).

$\mathrm{GC}$ of the $\mathrm{F}_{1}$ fractions was performed using a Carlo Erba 5300 Mega series gas chromatograph equipped with a flame-ionization detector (FID) and an on-column injection. A 25-m fused silica capillary column $(0.32 \mathrm{~mm}$ i.d.) coated with DB-5 stationary phase (J\&W Inc.) was used with hydrogen carrier gas $\left(2 \mathrm{~mL} / \mathrm{min}\right.$ at $\left.250^{\circ} \mathrm{C}\right)$. The oven was programmed from $40^{\circ} \mathrm{C}$ to $300^{\circ} \mathrm{C}$ at $5^{\circ} \mathrm{C} / \mathrm{min}$ and held at $300^{\circ} \mathrm{C}$ for $10 \mathrm{~min}$. GC-MS was performed on a Hewlett Packard MSD system. A 30-m (0.32 mm i.d.) fused silica capillary column (J $\& \mathrm{~W}$ Inc.) was used with auto splitless injection $\left(250^{\circ} \mathrm{C} ; 1.0 \mu \mathrm{L}\right)$ and helium as the carrier gas $(70 \mathrm{kPa})$. Mass spectra were obtained by electron impact mass spectrometry $(70 \mathrm{eV})$, scanning between 35 and 500 Daltons (ion source temperature, $250^{\circ} \mathrm{C}$ ).

\section{RESULTS SEM-based studies}

Reconnaissance studies of the entire diatomaceous S5 sapropel in Hole 971C were undertaken to characterize general variation in microfabrics. BSEI of the laminated diatomaceous sapropel reveals that at least three distinct lamina types are present. An ultra-high resolution study of $30 \mathrm{~cm}$ of the section with intact laminae (interval 160971C-2H-3, 99-129 cm) has provided descriptions of the composition and diatom floras within at least 500 laminae and sublaminae. The results of the intervals subsampled for detailed micropaleontological analysis are given in Table 2 and shown in Figure 5.

\section{Mineralogenic Sediment Laminae}

The pale laminations clearly visible on the core photo (Pl. 1) are predominantly of mineralogenic debris. BSEI observation shows them to comprise variable quantities of silt and clay occurring irregularly and with highly variable thickness from $100 \mu \mathrm{m}$ to $5 \mathrm{~mm}$. The boundaries of these laminae may be sharp or diffuse. Their spacing is irregular, and they may occur in bundles, quite closely spaced or in isolation.

These laminae are interpreted to be related to the activity of the adjacent Napoli mud volcano, originating either from downslope reworking of mud volcano deposits (by low density turbidity currents) and/or by direct downslope movement of mud volcano ejecta.

\section{Diatom Ooze/ Mixed Laminae}

In marked contrast to the abiogenic sediment laminae, distinct diatom ooze laminae or sublaminae are only obvious from BSEI exam- 


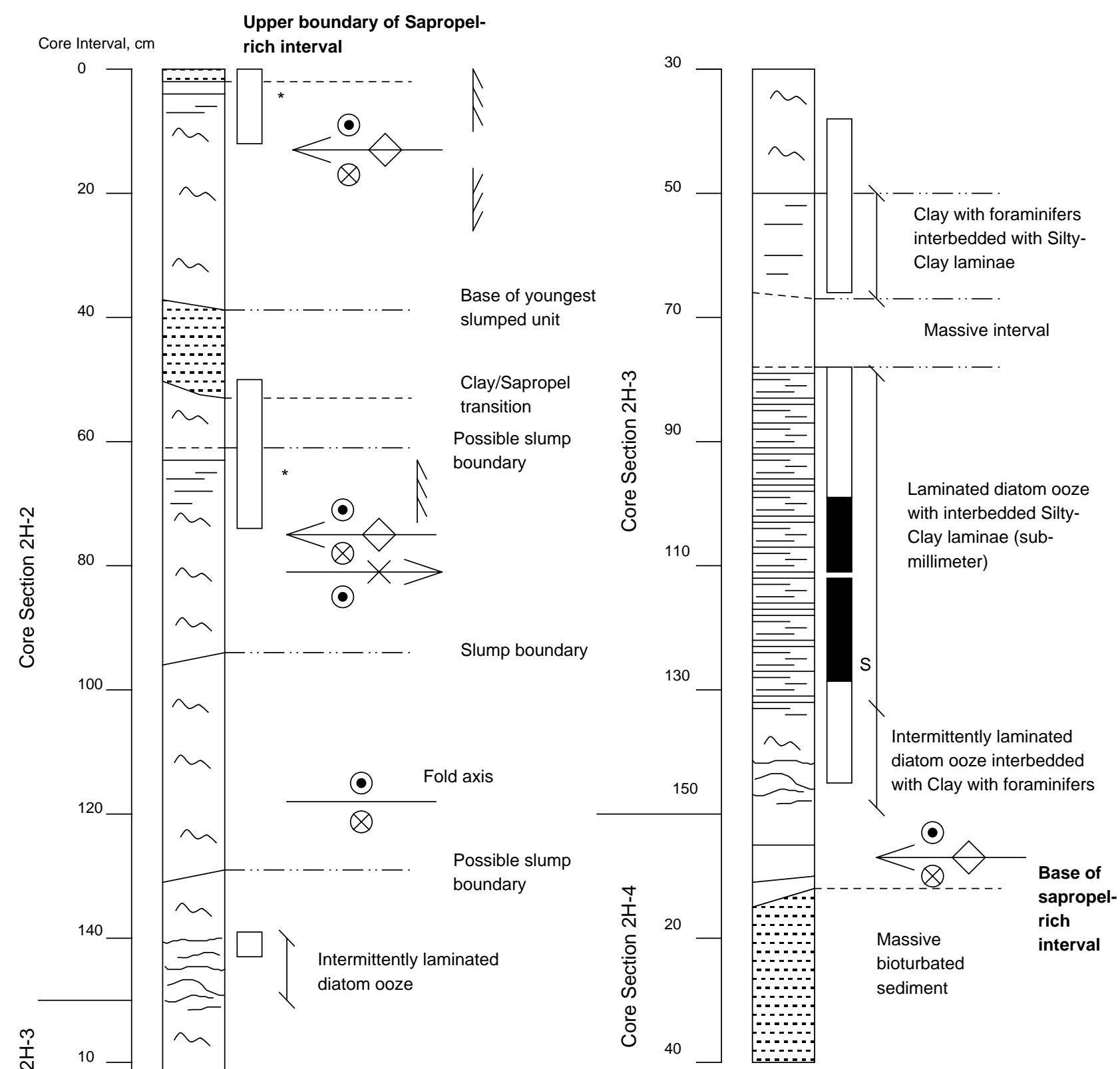

${ }^{*}$ Clay with Foraminifers interbedded with Silty-Clay laminae. The second of these two sequences is probably a repetition of the first.
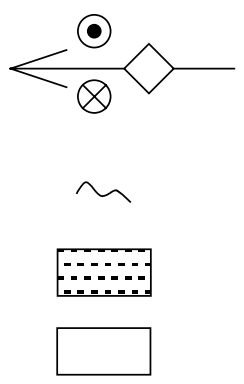

Fold axis showing direction of plunge and likely dip directions

Disrupted/chaotic bedding

Background sediment

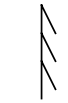

Direction of younging based on available geological evidence

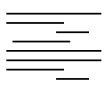

Laminated sediment

Lithological boundary

Sapropel sediment

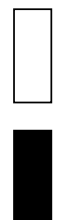

Interval sectioned for SEM studies

Interval examined in ultra-high resolution SEM studies

Interval subsampled for biomarker/diatom analysis

Figure 4. Detailed core summary of the diatom ooze sapropel cored from interval 160-971C-2H-2 through 160-971C-2H-4, $20 \mathrm{~cm}$, showing structural and lithologic characteristics, together with the intervals examined as part of this study. 


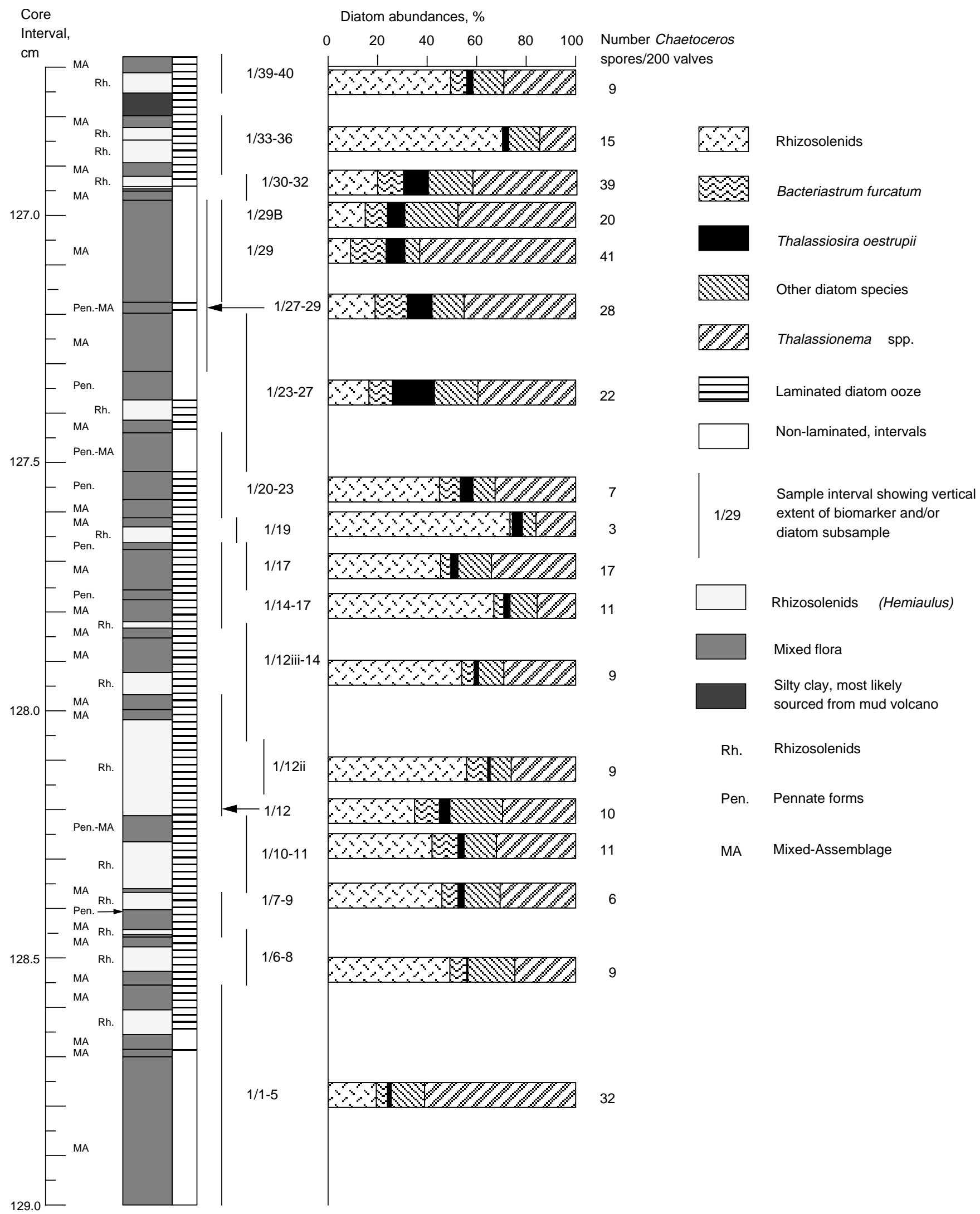

Figure 5. The lithology and diatom flora of the 2.5-cm subsampled interval 160-971C-2H-3, 126.5-129 cm (see Fig. 4, and Pl. 1). The intervals subsampled for biomarker and/or diatom analysis are indicated. 

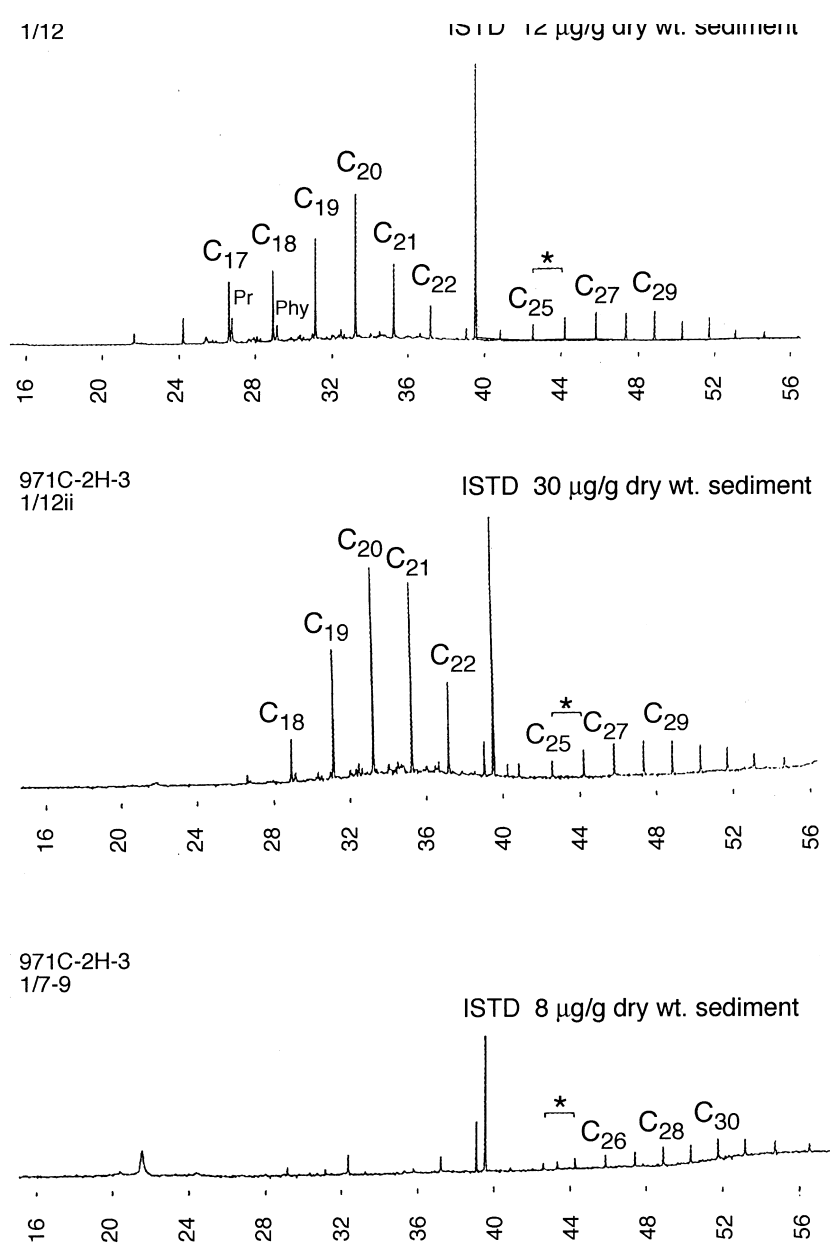

$971 \mathrm{~A} / 6$

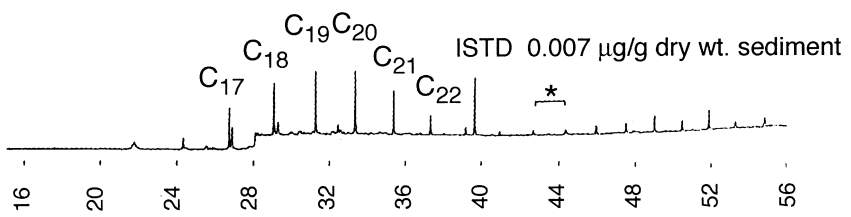

Figure 6. Gas chromatograms of the $F_{1}$ (hydrocarbon) fractions of sediment extracts for the diatom biomarker studies. ISTD =2,21-dimethyldocosane; $\mathrm{Pr}$ $=$ pristane Phy $=$ phytane $; \mathrm{C}_{17}-\mathrm{C}_{30}=$ n-alkanes; $*$ = expected $\mathrm{C}_{30} \mathrm{HBI}$ retention time.

ination (Fig. 7; Pl. 2). Differing porosities that give rise to different BSEI intensity are due to variation in diatom species, the extent to which diatoms are fragmented, and, less importantly, the calcareous nannofossil and detrital content (Fig. 7). To aid in the identification of diatoms, small sediment subsamples were examined in topographic imagery (Pl. 3). The diatoms are in an excellent state of preservation compared to other samples from the Eastern Mediterranean (compare Pl. 3, Figs. 1, 2).

The lamina fabric is defined by an alternation of laminae containing near-monospecific concentrations of rhizosolenid diatoms (fami-
Table 1. Summary of samples analyzed in the biomarker studies.

\begin{tabular}{|c|c|c|c|c|}
\hline $\begin{array}{l}\text { Core, } \\
\text { section }\end{array}$ & Sample & $\begin{array}{c}\text { Wet } \\
\text { weight } \\
\text { (mg) }\end{array}$ & $\begin{array}{c}\text { Dry } \\
\text { weight } \\
(\mathrm{mg})\end{array}$ & $\begin{array}{l}\text { Mass of total } \\
\text { hexane extract }\end{array}$ \\
\hline \multicolumn{5}{|l|}{$160-971 C-$} \\
\hline $2 \mathrm{H}-3$ & $1 / 33-36$ & 292.5 & 99.4 & $0.1 \mathrm{mg}(1 \mu \mathrm{g} / \mathrm{mg})^{*}$ \\
\hline $2 \mathrm{H}-3$ & $1 / 39-40$ & 344.3 & 132.1 & - \\
\hline $2 \mathrm{H}-3$ & $1 / 19$ & 18.5 & 18.0 & $(27.7 \mu \mathrm{g} / \mathrm{mg})^{*}$ \\
\hline $2 \mathrm{H}-3$ & $1 / 12 \mathrm{ii}$ & 29.4 & 16.5 & \\
\hline $2 \mathrm{H}-3$ & $1 / 12$ & 154.2 & 42.9 & $0.2 \mathrm{mg}(4.7 \mu \mathrm{g} / \mathrm{mg})^{*}$ \\
\hline $2 \mathrm{H}-3$ & $1 / 7-9$ & 187.4 & 63.9 & - \\
\hline $160-971 \mathrm{~A}$ & $6^{\dagger}$ & 1250.4 & 680.06 & $0.4 \mathrm{mg}(0.6 \mu \mathrm{g} / \mathrm{mg})^{*}$ \\
\hline
\end{tabular}

Notes: ${ }^{\dagger}=$ Sample $160-971 \mathrm{~A}-1 \mathrm{H}-3,44-45 \mathrm{~cm} . *$ = values as $\mu \mathrm{g} / \mathrm{mg}$ dry weight of sediment. $-=$ mass was not measurable.

ly Rhizosoleniaceae) and laminae containing more mixed diatom assemblages with variable amounts of calcareous material and clay (Fig. 7). In some thin intervals, fine laminae cannot be readily defined, and there is evidence that some slight bioturbation may have occurred.

\section{Rhizosolenid Laminae}

The dominant species, generally comprising over $90 \%$ of rhizosolenid laminae is Pseudosolenia calcar-avis (Pl. 3, 4; Table 2). Rhizosolenia styliformis is also present with abundances of between $5 \%$ and $10 \%$ with more minor amounts of Rhizosolenia setigera, Rhizosolenia bergonii, Proboscia alata, and very rare Rhizosolenia imbricata. A minor, but significant number of Hemiaulus-rich laminae occur in place of the rhizosolenid laminae, and in one exceptional instance, a monospecific lamina of Ethmodiscus spp. fragments occurs in the position normally occupied by a rhizosolenid lamina (Fig. 7; Pl. 3, Fig. 4). The mean thickness of rhizosolenid laminae is about $275 \mu \mathrm{m}$, but with a wide range from 10 to $2150 \mu \mathrm{m}$. Micropaleontological study of two other diatom-bearing sapropels (Sapropel S5 at Site 967 and the Pliocene "e" bed at Site 969; see Kroon et al., Chap. 14 , this volume) give a similar pattern of abundance showing diatom floras dominated by Pseudosolenia calcar-avis (Kemp et al., Chap. 27 , this volume).

\section{Mixed Laminae}

These contain mixed assemblages of pennate diatoms (dominantly Thalassionema frauenfeldii and Thalassionema nitzschiodes), Chaetoceros spp. setae, rhizosolenid diatoms (dominantly Pseudosolenia calcar-avis), Hemiaulus spp., and variable amounts of coccolith debris and clay, often arranged in sublaminae or discontinuous blebs (Pl. 3, 4; Fig. 5). Occasionally interbedded with mixed assemblage laminae are distinct sublaminae comprised of Thalassionema spp. The mean thickness of mixed laminae are about $300 \mu \mathrm{m}$, with a wide range from 10 to $2000 \mu \mathrm{m}$.

\section{Biomarker studies}

Concentrations of total hexane extracts in the seven sediment samples examined ranged from unweighable to $\sim 28 \mu \mathrm{g} / \mathrm{mg}$ dry sediment (Table 1). Gas chromatograms and GC-MS total ion current chromatograms recorded numerous common sedimentary hydrocarbons including $n$-alkanes (mainly $\mathrm{C}_{16}-\mathrm{C}_{30}$ ) and pristane and phytane (Fig. 6). However, the expected $\mathrm{C}_{30} \mathrm{HBI}$ hydrocarbons were not detected. Components eluting at the expected retention indices of the HBIs did not give the expected mass spectra. Nor were the expected $\mathrm{C}_{20}$ or $\mathrm{C}_{25}$ HBIs detected.

The known hydrocarbon biomarkers of Rhizosolenia setigera were not abundant in the sediment samples analyzed from the diatom ooze Sapropel S5 in Hole 971C, or from the opal-poor Sapropel S5 in Hole 971A. There are several possible explanations: (1) Rhizosolenia setigera may not produce hydrocarbon biomarkers; (2) the 
Table 2. Diatom species composition and abundance from the $S 5$ sapropel, interval 160-971C-2H-3, 126-129 cm.

\begin{tabular}{|c|c|c|c|c|c|c|c|c|c|c|c|c|c|c|c|c|c|c|}
\hline Sample: & $\begin{array}{l}\text { f } \\
\text { ò } \\
\text { @ે }\end{array}$ & 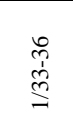 & $\begin{array}{l}\text { है } \\
\text { हூ } \\
\end{array}$ & $\stackrel{\text { ڤิ }}{\mathrm{S}}$ & $\stackrel{\text { సे }}{1}$ & 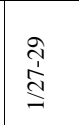 & $\begin{array}{l}\hat{N} \\
\stackrel{\Delta}{\Delta}\end{array}$ & $\begin{array}{l}\text { సి } \\
\text { ஸे } \\
\text { S }\end{array}$ & $\stackrel{\varrho}{\Xi}$ & 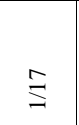 & $\stackrel{\bar{J}}{\stackrel{ \pm}{S}}$ & $\begin{array}{l}\frac{J}{J} \\
: \\
\stackrel{J}{\Xi}\end{array}$ & $\stackrel{:=}{\stackrel{\Xi}{\Xi}}$ & $\stackrel{\Xi}{I}$ & $\stackrel{\bar{J}}{\stackrel{0}{S}}$ & $\stackrel{9}{\leftrightarrows}$ & 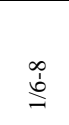 & $\stackrel{n}{s}$ \\
\hline $\begin{array}{l}\text { Actinocyclus octonarius Ehrenberg } \\
\text { Actinoptychus senarius } \text { Ehrenberg }\end{array}$ & & & $\begin{array}{l}2 \\
1\end{array}$ & 3 & 1 & & 4 & 1 & 1 & 1 & & 1 & & & & 1 & 1 & \\
\hline Anphora ovalis Kutzing & & & & 1 & & & & & & 1 & & 1 & & 1 & & & & 1 \\
\hline $\begin{array}{l}\text { Asteromphalus arachne (Breb.) Ralfs } \\
\text { Asterolampra grevillei (Wallich) Greville }\end{array}$ & 1 & & & & & & & & & & & & & & & & & 1 \\
\hline Asterolampra marylandica Ehrenberg & & 2 & 4 & 4 & 3 & 3 & 1 & 1 & 3 & 1 & 1 & 2 & & 4 & & & 1 & 3 \\
\hline alus flabellati & & & & & 2 & & 1 & & & & & & & & & & & \\
\hline $\begin{array}{l}\text { Asteromphalus robustus Castracane } \\
\text { Asteromphalus roperianus (Greville) Ralfs }\end{array}$ & 1 & & 1 & 2 & & & 1 & & 1 & & & & & 1 & & & 1 & \\
\hline Azpeitia nodulifera (Schmidt) Fryxell et Sims & 1 & 1 & & & & 1 & & & & & 2 & & & & & & & \\
\hline Azpeitia tabulifera (Grunow) Fryxell et Sims & & 1 & 2 & & & 2 & & & & 1 & & 1 & & & 1 & & & \\
\hline $\begin{array}{l}\text { Bacteriastrum furcatum Shadbolt } \\
\text { Cocconeis scutellum Ehrenberg }\end{array}$ & & 13 & 21 & 18 & 30 & $\begin{array}{r}26 \\
1\end{array}$ & 19 & 17 & 2 & $\begin{array}{r}12 \\
1\end{array}$ & 8 & 10 & 17 & 21 & 23 & 13 & 14 & 9 \\
\hline Coscinodiscus radiatus Eh & 2 & & & & 3 & 2 & & & & & & & & 2 & & & 1 & 1 \\
\hline $\begin{array}{l}\text { Coscinodiscus thorii Pavillard } \\
\text { Coscinodiscus spp. }\end{array}$ & & & 4 & 1 & 2 & 2 & & & & & & & & 1 & & & & 3 \\
\hline $\begin{array}{l}\text { Coscinodiscus } \mathrm{s} \\
\text { Cyclotella caspi }\end{array}$ & & 1 & 1 & 1 & 1 & & $\begin{array}{l}2 \\
1\end{array}$ & 3 & & 3 & 4 & & 2 & & 1 & & & 3 \\
\hline Cyclot & & & & 1 & 1 & & 2 & 1 & & 1 & & & & & & & & \\
\hline $\begin{array}{l}\text { Cymatosira lorenziana Grunow } \\
\text { Delphineis surirella (Ehr.) Andrews }\end{array}$ & & & 1 & 2 & 2 & & $\begin{array}{l}3 \\
1\end{array}$ & & 1 & 2 & & & 1 & 1 & 1 & & 1 & \\
\hline $\begin{array}{l}\text { Diploneis ovalis (Hilse) Cleve } \\
\text { Fragilariopsis doliolus (Wallich) Medlin \& S }\end{array}$ & & & & & 1 & & & & & & & & & 1 & 1 & 1 & 1 & \\
\hline Grammatophor & & & 2 & 3 & & 2 & 1 & & & 2 & & & & & & & 1 & 1 \\
\hline $\begin{array}{l}\text { Hemiaulus hauckii Grunow } \\
\text { Hemidiscus cuneiformis Wallich }\end{array}$ & 3 & 1 & 1 & 1 & 2 & & 2 & & & & 2 & 2 & 3 & 2 & 9 & 7 & 5 & 1 \\
\hline $\begin{array}{l}\text { Mastogloia decipiens Hustedt } \\
\text { Melosira westii W.Smith }\end{array}$ & & & & 1 & & & 1 & & 1 & & & & 1 & & & & & \\
\hline Heiden & & & 1 & 1 & & & 1 & & & & & & & & & & & \\
\hline $\begin{array}{l}\text { Nitzschia bicapitata Cleve } \\
\text { Nitzschia braarudii Hasle }\end{array}$ & 1 & 1 & 2 & 2 & 1 & & 2 & 1 & 2 & $\begin{array}{l}1 \\
2\end{array}$ & & 4 & $\begin{array}{l}3 \\
1\end{array}$ & $\begin{array}{l}6 \\
2\end{array}$ & 1 & 1 & 5 & 1 \\
\hline Nitzsc & & & & & & & 1 & 1 & & 1 & & 2 & & & & & & 1 \\
\hline mons & 8 & 6 & 3 & 1 & 5 & 1 & 5 & 3 & & 3 & 3 & 3 & 1 & 8 & 3 & 3 & 4 & 2 \\
\hline $\begin{array}{l}i \text { Grunow } \\
\text { unow }\end{array}$ & & 1 & & 1 & & & 1 & 1 & & 1 & & 1 & & 1 & 2 & & & \\
\hline 型 & 1 & & 1 & 1 & 1 & 2 & & 1 & 1 & 1 & & 1 & 1 & 1 & 1 & & & \\
\hline ane) Hustedt & 1 & 3 & & & & 1 & & 1 & 1 & 1 & & 1 & & 1 & 2 & 1 & & \\
\hline $\begin{array}{l}\text { Martyana martyi Heribaud } \\
\text { Paralia sulcata (Ehr.) Cleve }\end{array}$ & & & 1 & 1 & 1 & & & 1 & 1 & & & & & & & & & \\
\hline $\begin{array}{l}\text { Pinnularia borealis Ehrenbe } \\
\text { Pseudotriceratium punctatun }\end{array}$ & & & & 1 & & & & 1 & & & & & & & & & & \\
\hline $\begin{array}{l}\text { Pseudo } \\
\text { Probos }\end{array}$ & 2 & 1 & 3 & & & 1 & & & 1 & & 1 & & & 1 & 1 & 3 & 4 & \\
\hline (Schultz) Sundstrom & 128 & 87 & 34 & $\begin{array}{r}25 \\
3\end{array}$ & $\begin{array}{r}16 \\
2\end{array}$ & 34 & $\begin{array}{r}20 \\
2\end{array}$ & 84 & 136 & 85 & 111 & 74 & 85 & 40 & 70 & 83 & 86 & 36 \\
\hline $\begin{array}{l}\text { Rhizg } \\
\text { Rhizo }\end{array}$ & & & & & & & & & & & 1 & & 1 & & & & & \\
\hline & & 1 & 2 & & & & 1 & 2 & & 1 & 7 & 20 & 4 & 1 & & 3 & & \\
\hline $\begin{array}{l}\text { Rhizosolenia styliformis Brightwell } \\
\text { Stellarima stellaris (Roper) Hasle \& Sims }\end{array}$ & 13 & 11 & 4 & 5 & 1 & 4 & $\begin{array}{r}12 \\
1\end{array}$ & 4 & 11 & 1 & 16 & 4 & 23 & 29 & 12 & 9 & 9 & 3 \\
\hline Terp. & & & & & & & & 1 & & & & & & & & & & \\
\hline & & & 2 & & 2 & 1 & & & & & & 2 & 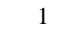 & & & 3 & & 2 \\
\hline$T I$ & 18 & 41 & 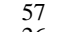 & 7 & $\underbrace{1}$ & & 69 & 48 & 23 & 61 & 23 & & 3 & 35 & 5 & 50 & 3 & 91 \\
\hline & 11 & 17 & 26 & 22 & 33 & 34 & 10 & 17 & 9 & 7 & 8 & 12 & 16 & 24 & 12 & 11 & 13 & 31 \\
\hline $\begin{array}{l}\text { (Ehr.) Cleve } \\
\text { ise }\end{array}$ & 1 & & 4 & 4 & & 1 & 1 & 1 & & & & & & 2 & 1 & 1 & 1 & \\
\hline $\begin{array}{l}\text { a lineata Jouse } \\
\text { a oestrupii (Ostefeld) Hasle } \\
\text { a spp. }\end{array}$ & 4 & 5 & 20 & 14 & 15 & 20 & 34 & 10 & 7 & 6 & 5 & 3 & 2 & 7 & 5 & 5 & 1 & 3 \\
\hline gissima Cleve \& Grunow & 2 & $\begin{array}{l}1 \\
2\end{array}$ & 1 & 5 & 1 & 2 & 3 & 1 & 1 & 5 & 1 & 1 & 1 & 4 & 3 & 5 & 8 & 5 \\
\hline ( & 200 & 200 & 200 & 200 & 200 & 200 & 200 & 200 & $200 \quad 2$ & 200 & 200 & 200 & 200 & 200 & 200 & 200 & 200 & 200 \\
\hline $\begin{array}{l}\text { Diatom abundance in valves per gram (dry weight) } \\
\text { Chaetoceros snp }\end{array}$ & 1.39 & $\begin{array}{l}9 \\
1.77\end{array}$ & $\begin{array}{l}1.11 \\
39\end{array}$ & $1 \quad 1.26$ & $\begin{array}{ll}6 & 1.67 \\
41\end{array}$ & 1.22 & 1.39 & $9 \quad 1.95$ & $5 \quad 1.56$ & 2.6 & 1.56 & 3.9 & 2.6 & 2.23 & $\begin{array}{ll}3 & 1.95\end{array}$ & 1.77 & 5.2 & 1.9 \\
\hline Cha & & & & & & & & & & & & & & 10 & 11 & 6 & 9 & 32 \\
\hline
\end{tabular}

Note: The figures for diatom abundance in valves per gram (dry weight) are given to the power of $10^{8} / \mathrm{g}$.

abundances of Rhizosolenia setigera (identified by microscopy) may not have been sufficient to produce detectable masses of material; (3) the $\mathrm{C}_{30} \mathrm{HBI}$ alkenes may have reacted with sulphur, producing related HBI thiophenes and thiolanes, which may be present in the unexamined F2 fraction; (4) Rhizosolenia spp. may only produce $\mathrm{C}_{30} \mathrm{HBIs}$ under restricted phytogenetic conditions (e.g., specific salinities, temperatures). Each of these requires further investigation.

\section{DISCUSSION}

\section{Paleoecological Significance of Diatom Floras}

The BSEI studies of thin sections and topographic SEM imagery may be combined with the results of the conventional micropaleontological analysis. A brief review of the ecology/ paleoecology of the major diatom genera/ species recorded is presented. This is used as a basis for a paleoecological model for the generation of the sequential fluxes recorded in the laminated sapropel.

The diatom flora within the mixed layer commonly contains Thalassionema spp., and to a lesser extent Chaetoceros spp., both of which are rapidly growing genera characteristic of diatom blooms. These genera have been documented both in seasonal blooms (e.g., Ignatiades, 1969) as well as the late summer bloom associated with input of floodwater from the Nile river (prior to the Aswan Dam; Halim et al., 1967). An intriguing difference of the S5 laminae with previous SEM studies, which have been mainly undertaken on coastal upwelling areas, is the absence of near-monospecific laminae of Chaetoceros spp. resting stages (cf. Brodie and Kemp, 1994; Lange and Schimmelmann, 1994; Bull and Kemp, 1995; Grimm et al., 1996). 


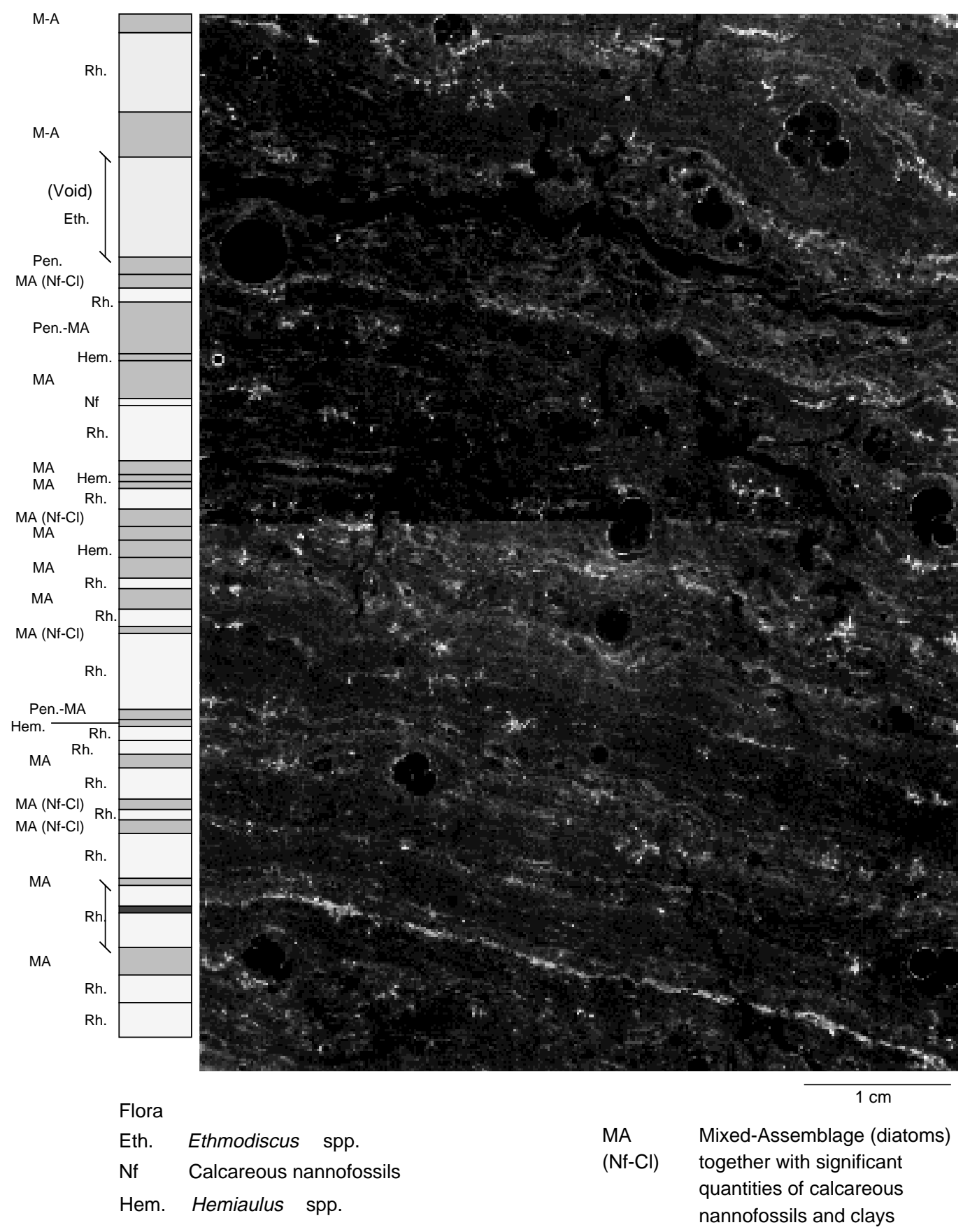

Figure 7. BSEI of part of the laminated diatom ooze interval across interval $160-971 \mathrm{C}-2 \mathrm{H}-3,121-125 \mathrm{~cm}$. The rhizosolenid laminae are typically a dark BSEI tone, and the mixed assemblage laminae a light BSEI tone. An abiogenic lamina toward the top of the image has a very pale BSEI tone. Planktonic foraminifers, probably Globigerinoides ruber and Orbulina universa, are present throughout the laminated interval within both rhizosolenid laminae and mixed assemblage laminae. Euhedral salt crystals on, and probably within, the thin section are evidenced by an intense white BSEI tone.

\section{Ecology and Mechanisms of Deposition of Pseudosolenia calcar-avis and Associated Rhizosolenids}

Rhizosolenid diatoms are generally characteristic of stratified oligotrophic waters (Guillard and Kilham, 1978). Pseudosolenia calcar-avis is characteristic of the Mediterranean and is one of the few species that persist through nutrient-poor conditions during the summer months (Margalef, 1967). Proboscia alata has also been noted to persist through the summer (Ignatiades, 1969). Rhizosolenids are not part of the modern spring bloom (Ignatiades, 1969; Schneller et al., 1985); indeed, the growth rates of such large diatoms are relatively slow (Guillard and Kilham, 1978). During summer months, however, they have been recorded in elevated numbers (Schneller et al., 1985).

Mat formation is a general characteristic of numerous oceanic Rhizosolenia species (Villareal and Carpenter, 1989). It has recently been shown that such mats are ideally adapted to a stratified water 
column as they are able to regulate their buoyancy, descending to the nutricline to take up nitrogen and ascending to the near-surface to photosynthesize (Villareal et al., 1993). Although most of the studied modern mats involve species other than the dominant Mediterranean species, massive fluxes of Pseudosolenia calcar-avis interpreted to represent sinking mats have been recorded off Oregon (Sancetta et al., 1991), and this species has been noted as a component of Rhizosolenia mats in the central North Pacific Gyre (Villareal and Carpenter, 1989).

Although rarely preserved in the sediment record, Sancetta et al. (1991), cited numerous plankton sample and sediment trap studies that led them to propose that mass sinking of rhizosolenid diatoms may be a common occurrence and that rapid loss of buoyancy of rhizosolenid mats may generate the large-scale sedimentation observed. Interestingly, many of these observations and periods of flux do not occur at the time of the normal spring "bloom," but commonly in autumn or winter (Sancetta et al., 1991).

Intriguingly, these observed concentrations of rhizosolenid diatoms may not be the result of rapid growth (a classical "bloom"), but rather the segregation of large colonial forms due to buoyancy effects. Marine snow, in general, (MacIntyre et al., 1995), and diatom mats in particular (Quilty et al., 1985), are known to accumulate on density interfaces. In Holocene laminated sediments from the Gulf of California, Pike and Kemp (1997) record flux of diatom mats of Thalassiothrix longissima together with Rhizosolenia spp. at the end of the summer, which they attribute to result from the breakdown of stratification.

Major oceanic frontal systems are also known to concentrate diatom mats (Barber et al., 1994; Yoder et al., 1994) and result in massive diatom flux sedimentation (Smith et al., 1996; Kemp and Baldauf, 1993). In the context of the Mediterranean at times of sapropel formation, however, it is unlikely that fronts equivalent in magnitude to those observed in the Eastern Equatorial Pacific (Barber et al., 1994; Yoder et al., 1994), would have been established to generate the widespread flux observed.

\section{The Annual Cycle}

Although we have no direct information on sedimentation rates within the diatomaceous S5 sapropel, the bulk sedimentation rate at the top of Hole 971B $(\sim 100 \mu \mathrm{m} / \mathrm{yr})$ and the repetitive and regular alternation of lamina types observed is consistent with a seasonal-scale variation in flux. Comparison of the bulk sedimentation rate with the mean couplet thickness of $575 \mu \mathrm{m}$ implies that sedimentation and/or preservation of material during deposition of Sapropel S5 in Hole 971C greatly exceeded that during periods of nonsapropel deposition. Analysis of the diatom species-composition of individual laminae reveals a probable annual cycle of deposition in the Mediterranean at the time of sapropel formation. Fall out from a seasonal spring or autumn bloom (the mixed assemblage and Thalassionema spp. layer) is recorded in a lamina of diatoms characteristic of rapid reproduction in conditions of relatively high nutrient availability. Increased monsoon-related input from the Nile (Rossignol-Strick et al., 1982) led to the injection of abundant nutrients into the Mediterranean, but these became trapped in the subsurface by enhanced stratification (Rohling, 1994). Vertically migrating mats of rhizosolenid diatoms were the best placed among the phytoplankton to exploit this deep, but rich, supply of nutrients. During the course of the summer, these mats reproduced to form a substantial biomass that was deposited en masse on the breakdown of stratification (Fig. 8).

\section{Opal Preservation and Dissolution in the Mediterranean}

Why are diatoms absent from most sapropels and why are they preserved in a few? The virtual absence of siliceous microfossils from recent sediments of the Mediterranean is a symptom of its status as the world's most nutrient-depleted sea. The levels of silicic acid at depth within the present-day Eastern Mediterranean (maximum of $14.6 \mu \mathrm{M})$ are much lower than those typical of the world ocean (e.g. $130 \mu \mathrm{M}$ in the Pacific and Indian Ocean and 40 to $100 \mu \mathrm{M}$ in the Atlantic Ocean; Krom et al., 1991).

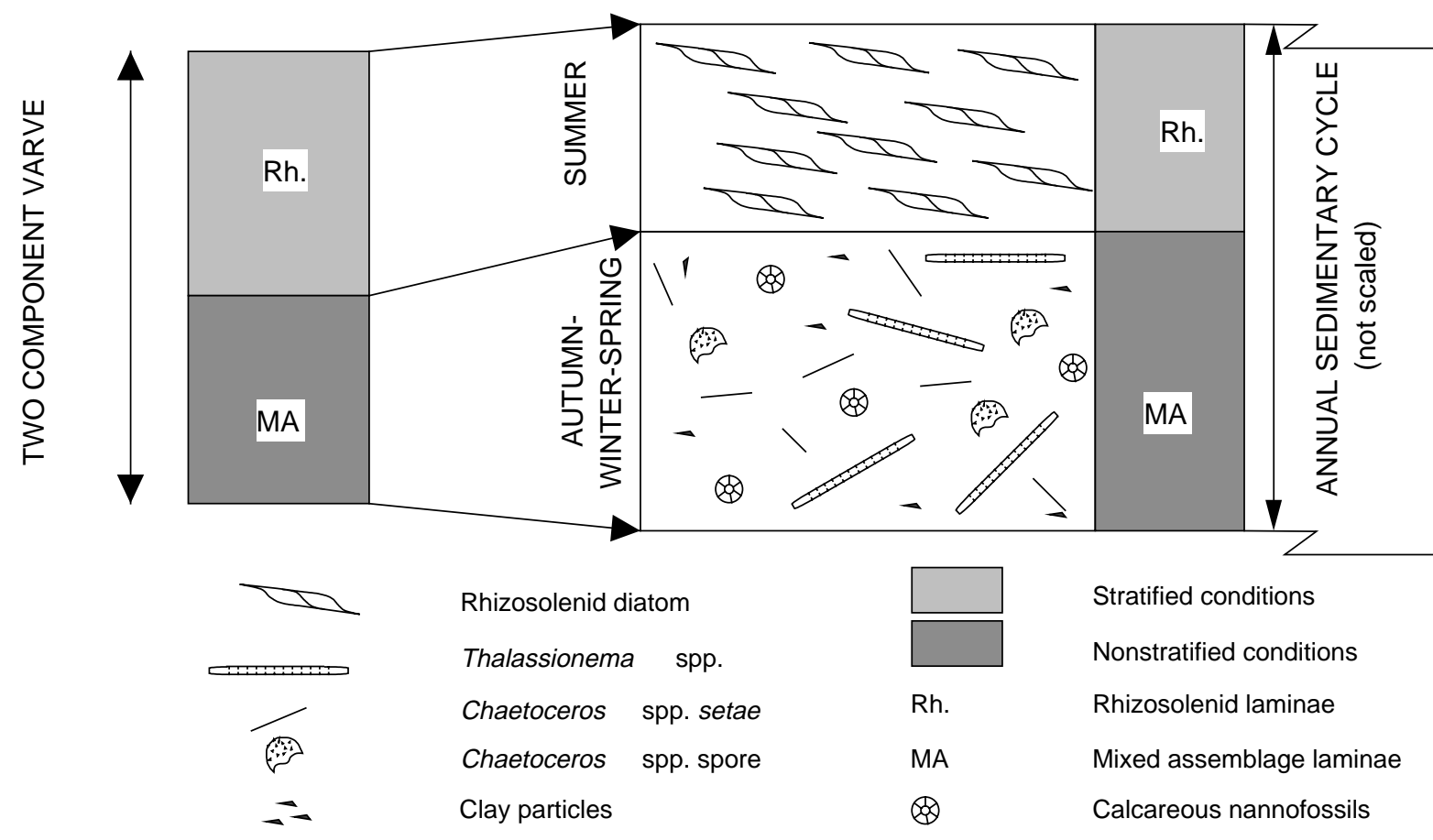

Figure 8. Schematic diagram of the two-component varve common within the laminated diatom ooze. 
The diatom preservation within the S5 sapropel located within the moat of the Napoli dome is quite exceptional for the Mediterranean basin (Pl. 3). The only other instances of diatom preservation within Quaternary sapropels in normal settings (other than those described by Kemp et al., Chap. 27, this volume) are those documented by Schrader and Matherne, (1981; see Fig. 1). In contrast to normal oxic environments, opal is very well preserved in late Quaternary sediments within anoxic basins (Bjorklund and De Ruiter, 1987; Erba et al., 1987), with excellent preservation of fine details of diatom frustules (Erba, 1991). The isolation of the anoxic waters within these depressions is enhanced by the increased density stratification produced by the upward penetration from the seafloor of saline fluids from the underlying Messinian evaporites.

In view of the excellent preservation of the diatoms and given its topographic depression, it seems that the moat of the Napoli dome acted, at least intermittently, as an anoxic basin after sapropel deposition, which preserved relatively silica-rich waters in contact with the sediment. In addition, slumping, which may have accelerated the burial of the sapropel, could also have aided opal preservation.

\section{CONCLUSIONS}

The moat of the Napoli mud volcano has acted as a natural sediment trap and geochemical buffer that has preserved a laminated diatomaceous S5 sapropel. Analysis of the diatom species variation in the laminae has demonstrated the preservation of a probable seasonal flux cycle, corresponding to a bloom of varied species, consistent with a mixing event. This alternates with a near-monospecific lamina of mat-forming diatoms that grew during the dominantly stratified conditions. The model proposed above suggests that the sapropels are largely diatom mat deposits and confirms the speculation of Sancetta (1994). There are many attractions to this: on the one hand, studies by Tang and Stott (1993) argue for stratification, but others (e.g., Calvert et al., 1992; Castradori, 1993) support high productivity. The answer is that there were not generally high rates of primary production but the rapid descent of the slowly growing mats produced high export production. The diatom mats were uniquely placed among the phytoplankton to exploit the nutrients trapped at depth. This model is also consistent with evidence from foraminifer data (Rohling, 1994) for a deep chlorophyll maximum - the foraminifers were grazing on the diatom mats.

\section{ACKNOWLEDGEMENTS}

The contributions of RBP and AESK were supported by funding under the UK ODP/NERC Science Program, Grant GST/02/1099, and JP acknowledges support from an ODP/NERC Research Fellowship (GT5/95/ODP/3). The referees are thanked for their comments.

\section{REFERENCES}

Barber, R.T., Murray, J.W., Jr., McCarthy, J.J., 1994. Biogeochemical interactions in the equatorial Pacific. AMBIO, 23:62-66.

Bjørklund, K.R., and De Ruiter, R., 1987. Radiolarian preservation in eastern mediterranean anoxic sediments. Mar. Geol., 75:271-281.

Brodie, I., and Kemp, A.E.S., 1994. Variation in biogenic and detrital fluxes and formation of laminae in late Quaternary sediments from the Peruvian coastal upwelling zone. Mar. Geol., 116:385-398.

Bull, D., and Kemp, A.E.S., 1995. Composition and origins of laminae in late Quaternary and Holocene sediments from the Santa Barbara Basin. In Kennett, J.P., Baldauf, J.G., and Lyle, M. (Eds.), Proc. ODP, Sci. Results, 146 (Pt. 2): College Station, TX (Ocean Drilling Program), 77-87.

Calvert, S.E., Nielsen, B., and Fontugne, M.R., 1992. Evidence from nitrogen isotope ratios for enhanced productivity during the formation of eastern Mediterranean sapropels. Nature, 359:223-225.
Castradori, D., 1993. Calcareous nannofossils and the origin of eastern Mediterranean sapropels. Paleoceanography, 8:459-471.

Cita, M.B., Broglia, C., Malinverno, A., Spezzibottiani, G., Tomadin, L., and Violanti, D., 1982. Late Quaternary pelagic sedimentation on the southern Calabrian Ridge and western Mediterranean Ridge, Eastern Mediterranean. Mar. Micropaleontol., 7:135-162.

Erba, E., 1991. Deep mid-water bacterial mats from anoxic basins of the Eastern Mediterranean. Mar. Geol., 100:83-101.

Erba, E., Rodoni, G., Parisi, E., Ten Haven, H.L., Nip, M., and De Leeuw, J.W., 1987. Gelatinous pellicles in deep anoxic hypersaline basins of the Eastern Mediterranean. Mar. Geol., 75:165-183.

Grimm, K.A., Lange, C.B., and Gill, A.S., 1996. Biological forcing of hemipelagic sedimentary laminae: evidence from ODP Site 893, Santa Barbara Basin, California. J. Sediment. Res., 66:613-624.

Guillard, R.R.L., and Kilham, P., 1978. Ecology of marine planktonic diatoms. In Werner, D. (Ed.), The Biology of Diatoms: Berkeley (Univ. Calif. Press), Botan. Monogr., 13:470-483.

Halim, Y., Guerges, S.K., and Saleh, H.H., 1967. Hydrographic conditions and plankton in the South East Mediterranean during the last normal Nile flood (1964). Int. Rev. Ges. Hydrobiol., 52:401-425.

Ignatiades, L., 1969. Annual cycle, species diversity and succession of phytoplankton in lower Saronicos Bay, Aegean Sea. Mar. Biol., 3:196-200.

Kemp, A.E.S., 1996. Palaecolimatology and palaeoceanography from laminated sediments. Geol. Soc. Spec. Publ. London, 116.

Kemp, A.E.S., and Baldauf, J.G., 1993. Vast Neogene laminated diatom mat deposits from the eastern equatorial Pacific Ocean. Nature, 362:141-144.

Krom, M.D., Brenner, S., Israilov, L., and Krumgalz, B., 1991. Dissolved nutrients, preformed nutrients and calculated elemental ratios in the South-East Mediterranean Sea. Oceanol. Acta, 14:189-194.

Lange, C.B., and Schimmelmann, A., 1994. Seasonal resolution of laminated sediments in Santa Barbara Basin: its significance in paleoclimatic studies. In Redmond, K.T., and Tharp, V.L. (Eds.), Proc. 10th Annu. Pacific Climate (PACLIM) Workshop. Tech. Rep.-Calif. Dep. Water Resour., 36:83-91.

MacIntyre, S., Alldredge, A.L., and Gotschalk, C.C., 1995. Accumulation of marine snow at density discontinuities in the water column. Limnol. Oceanogr., 40:449-468.

Margalef, R., 1967. The food web in the pelagic environment. Helg. Wiss. Meeresunters., 15:548-559.

Pike, J., and Kemp, A.E.S., 1996a. Preparation and analysis techniques for studies of laminated sediments. Geol. Soc. Spec. Publ. London, 116:3748.

, 1996b. Records of seasonal flux in Holocene laminated sediments from the Gulf of California. Geol. Soc. Spec. Publ. London, 116:157169.

, 1997. Early Holocene decadal-scale ocean variability recorded in Gulf of California laminated sediments. Paleoceanography, 12:227-238.

Quilty, P.G., Kerry, K.R., and Marchant, H.J., 1985. A seasonally recurrent patch of Antarctic planktonic diatoms. Search (ANZAAS), 16:48.

Robertson, A., Emeis, K.-C., Richter, C., Blanc-Valleron, M.-M., Bouloubassi, I., Cramp, A., DeLange, G.J., DiStefano, E., Flecker, R., Frankel, E., Howell, M.W., Janecek, T.R., Jurado-Rodriguez, M.-J., Kemp, A.E.S., Koizumi, I., Kopf, A., Major, C.O., Mart, Y., Pribnow, D.F.C., Rabaute, A., Roberts, A., Rullkotter, J.H., Sakamoto, T., Spezzaferri, S., Staerker, T.S., Stoner, J.S., Whiting, B.M., and Woodside, J.M., 1996. Mud volcanism on the Mediterranean Ridge-Initial results of Ocean Drilling Program Leg 160. Geology, 24:239-242.

Robson, J., and Rowland, S.J., 1988. Synthesis of a highly branched C30 sedimentary hydrocarbon. Tetrahedron Lett., 29:3837.

Rohling, E.J., 1994. Review and new aspects concerning the formation of eastern Mediterranean sapropels. Mar. Geol., 122:1-28.

Rossignol-Strick, M., Nesteroff, W., Olive, P., and Vergnaud-Grazzini, C., 1982. After the deluge: Mediterranean stagnation and sapropel formation. Nature , 295:105-110.

Sancetta, C., Villareal, T., and Falkowski, P. 1991. Massive Fluxes of Rhizosolenid diatoms: a common occurrence? Limnology and Oceanography, $36: 1452-1457$.

Sancetta, C., 1994. Mediterranean sapropels: Seasonal stratification yields high production and carbon flux. Paleoceanography, 9:195-196.

, 1996. Laminated diatomaceous sediments: controls on formation and strategies for analysis. Geol. Soc. Spec. Publ. London, 116:17-22.

Sancetta, C., Villareal, T., and Falkowski, P., 1991. Massive fluxes of rhizosolenid diatoms: a common occurrence? Limnol. Oceanogr., 36:14521457. 
Schneller, A., Kimor, B., and Azov, Y., 1985. Seasonal distribution of diatoms and dinoflagellates (> $65 \mu \mathrm{m})$ off the coast of Israel. Rapp. Comm. Int. Mer Mediterr., 29:115-119.

Schrader, H.J., and Matherne, A., 1981. Sapropel formation in the eastern Mediterranean sea: evidence from preserved opal assemblages. Micropaleontology, 27:191-203.

Smith, C.R., Hoover, D.J., Doan, S.E., Pope, R.H., Demaster, D.J., Dobbs, F.C., and Altabet, M.A., 1996. Phytodetritus at the abyssal seafloor across $10^{\circ}$ of latitude in the central equatorial Pacific. Deep-Sea Res. Part 2, 43:1309-1338.

Tang, C.M., and Stott, L.D., 1993. Seasonal salinity changes during Mediterranean sapropel deposition 9000 years b.P.: evidence from isotopic analyses of individual planktonic foraminifera. Paleoceanography, 8:473-493.

Villareal, T.A., Altabet, M.A., and Culver-Rymsza, K., 1993. Nitrogen transport by vertically migrating diatom mats in the North Pacific Ocean. Nature, 363:709-712.
Villareal, T.A., and Carpenter, E.J., 1989. Nitrogen fixation, suspension characteristics, and chemical composition of Rhizosolenia mats in the Central North Pacific gyre. Biol. Oceanogr., 6:327-345.

Volkman, J.K., Barrett, S.M., and Dunstan, G.A., 1994. $\mathrm{C}_{25}$ and $\mathrm{C}_{30}$ highly branched isoprenoid alkenes in laboratory cultures of two marine diatoms. Org. Geochem., 21:407-413.

Yoder, J.A., Ackleson, S., and Barber, R.T., and Flamant, P., and Balch, W.A., 1994. A line in the Sea. Nature, 371:689-692.

Date of initial receipt: 22 January 1997

Date of acceptance: 13 June 1997

Ms 160SR-016 


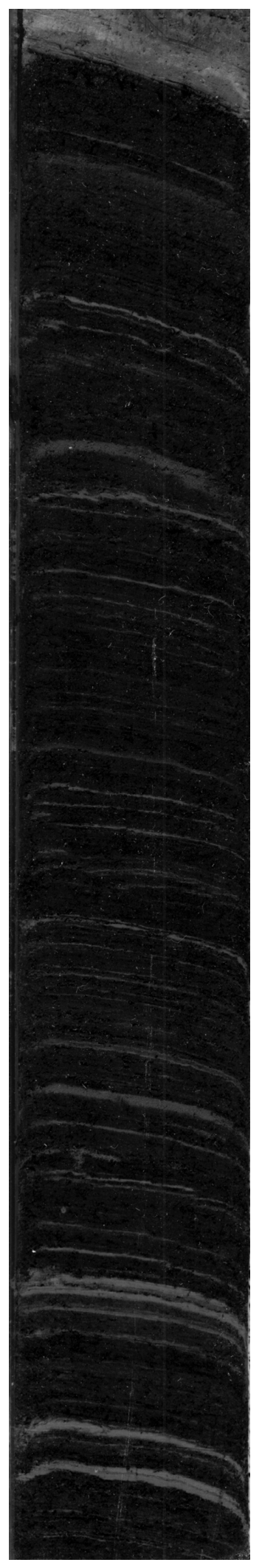

Plate 1. Core photograph of the intact laminated interval of the S5 sapropel within the moat of the Napoli mud volcano, interval 160-971C-2H-3, 78-122 $\mathrm{cm}$.

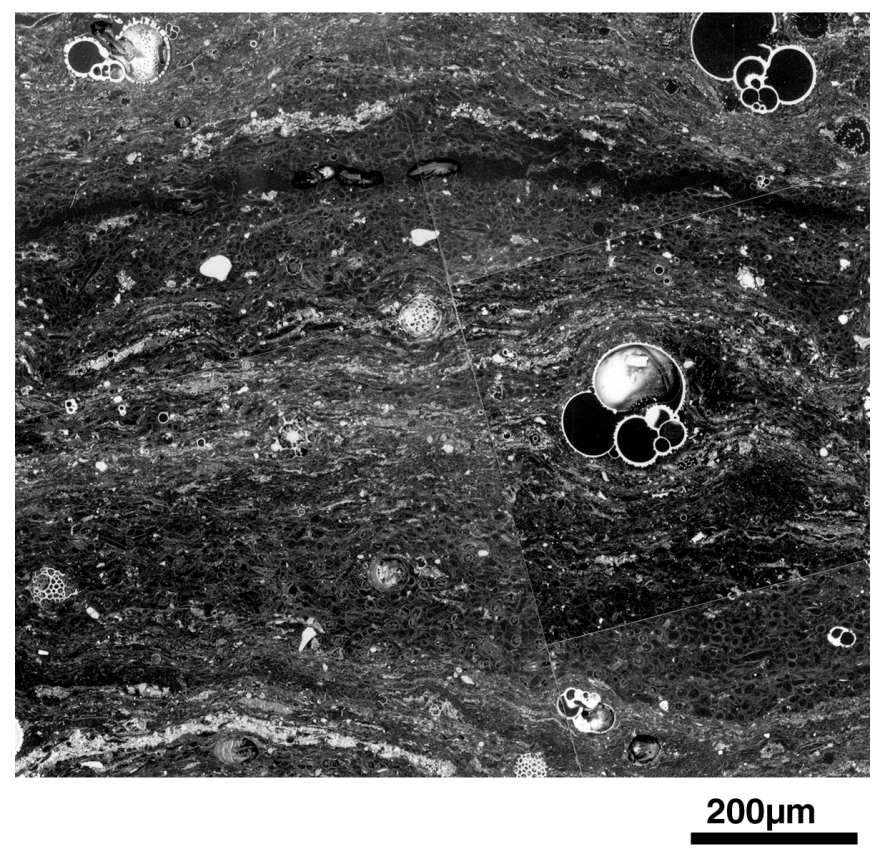

Plate 2. BSEI of several rhizosolenid and mixed assemblage laminae across interval $160-971 \mathrm{C}-2 \mathrm{H}-3,121-125 \mathrm{~cm}$. The rhizosolenid laminae are more porous than the mixed assemblage laminae, as evidenced by their darker BSEI tone, and thus their greater proportion of carbon-based resin with a low back-scatter coefficient. Note the occurrence of planktonic foraminifers, probably Globigerinoides ruber, within the mixed assemblage laminae. 

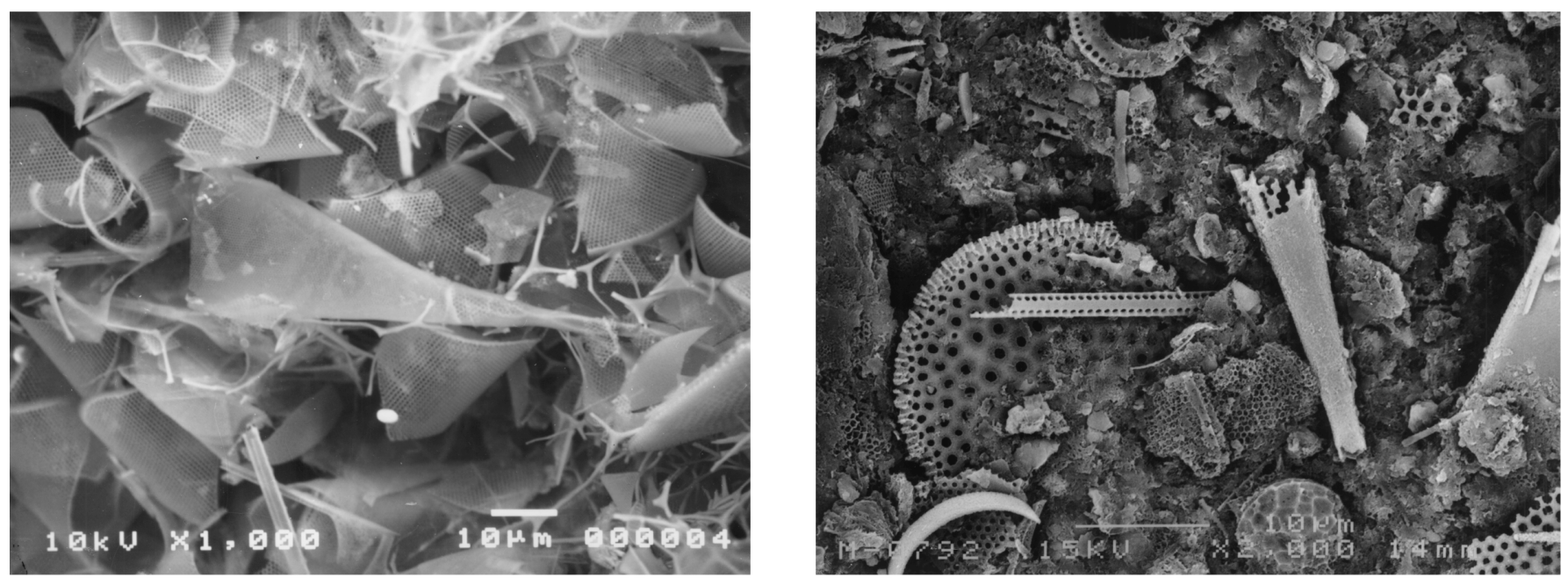

1

$10 \mu \mathrm{m}$

2

$10 \mu \mathrm{m}$

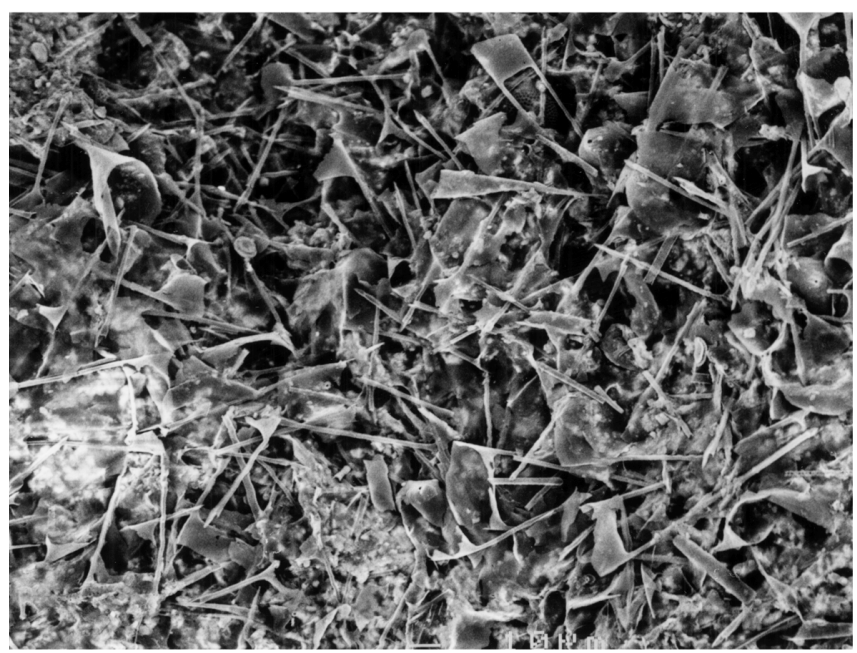

3

$20 \mu \mathrm{m}$

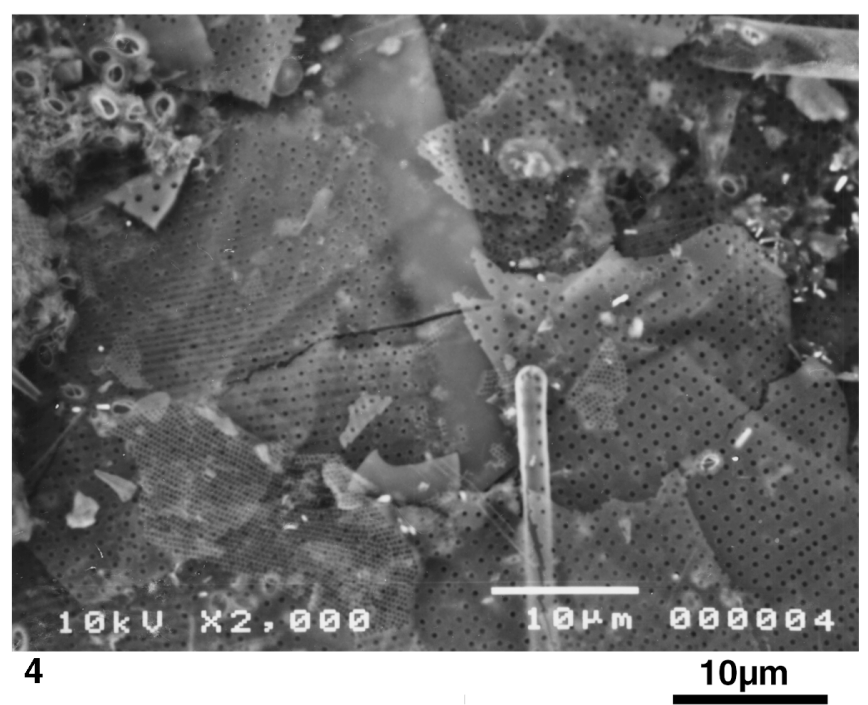

Plate 3. 1. Back-scatter electron (BSE) topographic image of a rhizosolenid-rich lamina (Sample 160-971C-2H-3, 126-129 cm). The areolae of the Rhizosolenia calcar-avis valve (centre) and the scale-like girdle bands surrounding it are both well preserved. 2. By contrast, a BSE topographic image of diatom-rich material from the "e" bed (Pliocene Sapropel 47), Sample 160-969D-5H-2, 53-57.5 cm. Note the etched Proboscia alata frustule fragment in the foreground, together with other etched diatoms (The "e" bed is more fully described in Kemp et al., Chap. 27, this volume.) 3. BSE topographic image of a Hemiaulus-rich lamina (Sample 160-971C-2H-3, 106.5-111 cm). 4. BSE topographic image of Ethmodiscus lamina observed within sample 160-971C-2H-3, 121-125 cm. 

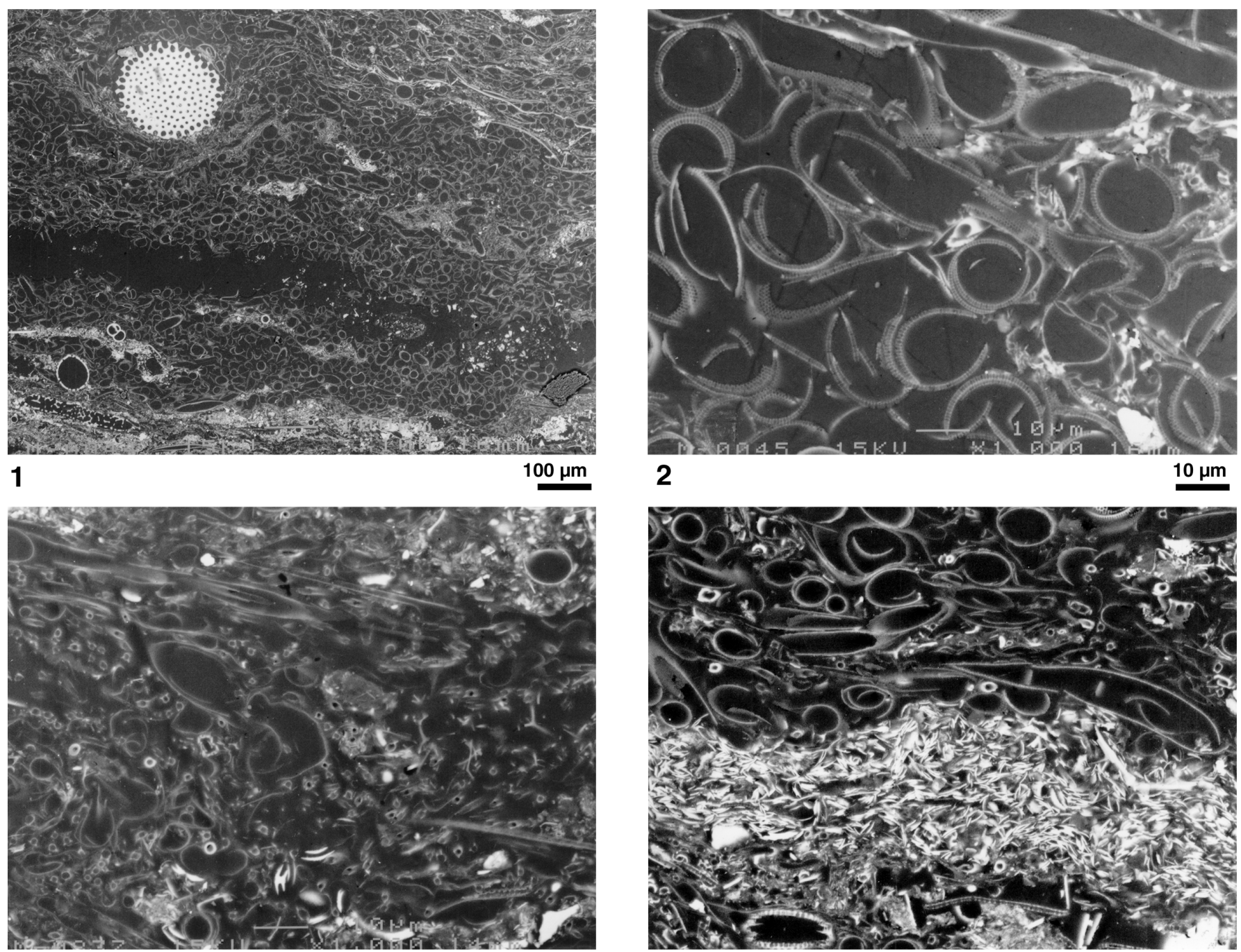

3

$10 \mu \mathrm{m}$

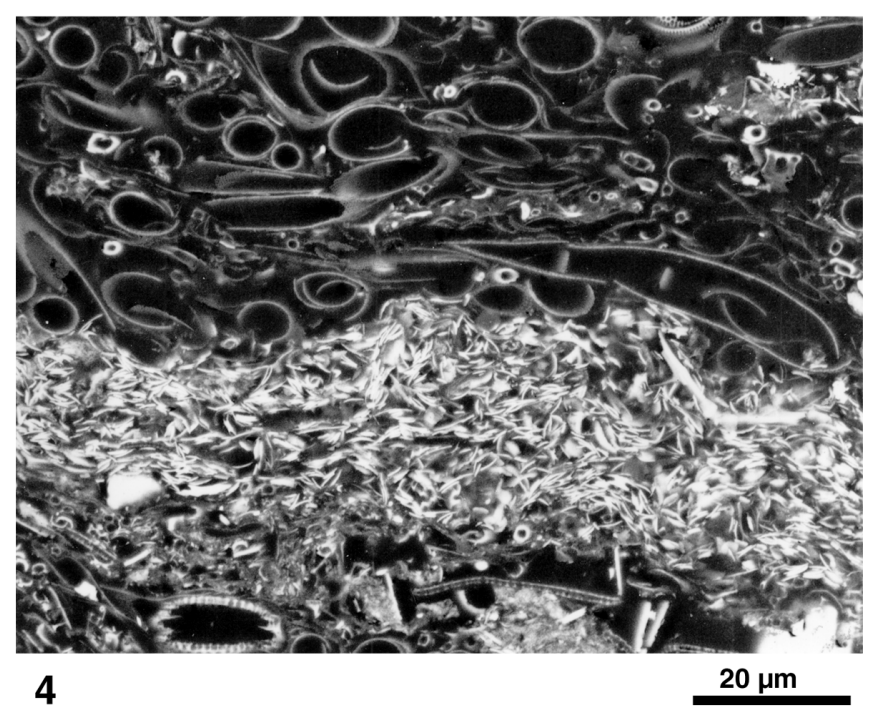

Plate 4. 1. BSEI of near-monospecific rhizosolenid lamina, dominated by girdle bands (Sample 160-971C-2H-3, 126-129 cm). 2. High magnification BSEI of rhizosolenid-rich lamina in 1. 3. BSEI of a lamina dominated by Hemiaulus spp. (Sample 160-971C-2H-3, 121-125 cm). 4. Mixed assemblage lamina comprising fragmented diatom valves overlain by calcareous coccoliths, and abruptly succeeded by a rhizosolenid lamina. 